\title{
Ethical Criticism: From Plato to Pluralism
}

If there is any agreement among literary theorists today, it may be the common observation that modern criticism is in a state of crisis. ${ }^{1}$ According to René Wellek, literary criticism entered a state of crisis in 1914. Paul de Man fixes on 1970 as the date when Continental influences pushed critical theory into chaos. Apparently, criticism has been in crisis throughout its history. The opening manifesto of the Stanford Literature Review traces the origin of the present crisis to the time of Plato, and indeed Plato is often named as the beginning of our current anxieties in literary theory. What kind of crisis endures for so many years? Can a crisis be one with the tradition itself?

A crisis is a state of affairs subject to little internal coherence or consistency, unless it be the order of disorder itself. It is a period of violent instability that threatens either to shift toward another

1. Concerning the relation between criticism and crisis, see Reinhart Koselleck, Kritik und Krise (Feiburg: Verlag Karl Alber, 1959); René Wellek, "The Crisis of Comparative Literature," Concepts of Criticism (New Haven: Yale University Press, 1963), pp. 282-95; Paul de Man, "Criticism and Crisis," Blindness and Insight (1971; reprint, Minneapolis: University of Minnesota Press, 1983), pp. 3-19; John Freccero, René Girard, and Alphonse Juilland, Foreword, Stanford Literature Review 1.2 (1984): 157-58; and William E. Cain, The Crisis in Criticism (Baltimore: Johns Hopkins University Press, 1984). 
chaotic state or to reach a state of resolution. For a crisis to be resolved, the proper pressure, the proper decision, must be applied within the untoward state of affairs. Even if one conceives of order and disorder as relative terms, or defines disorder as the dynamic passage between states of order, a question of perception still arises: how does a crisis remain in a perpetual state of crisis?

One way of addressing the apparent contradiction is to recognize that the crisis in literary theory is defined around the nature of criticism itself. The word "criticism," of course, derives from the Greek krinein, which means to cut, to separate, to divide, and to distinguish. On the one hand, criticism in its capacity to separate and divide would seem to be the traditional antidote to states of crisis, not the cause of disorder and lack of distinctions. It is only when the critical nature of criticism disappears that it may be said to be in crisis, for crisis turns upon the lack of those differences that criticism exists to create. In other words, criticism robbed of its differentiating talent falls into crisis. On the other hand, the current crisis in theory may have less to do with the ability to make critical decisions than with the suspicion of decision itself. Modern theory seems too aware of the relation between "criticism" and "cutting," and literary theorists have come increasingly to see critical decisions as the result of power and violence. Critical distinctions appear too arbitrary for modern tastes, and we have learned to suspect that arbitrariness conceals self-interest and aggressive willfulness. This is not an idle observation. The perception that criticism is violent is crucial to the ethics of criticism because it marks the point where literary theory and the ethical tradition begin to ask the same questions about the nature of human beings and their capacity for violence. Indeed, that the crisis of criticism derives in part from an ethical reaction to the perceived violence of the critical act reveals to what extent literary criticism and moral philosophy have a common history.

But the fact that literary criticism has an ethical dimension should shock more than it does. The wealth of critical literature on ethics and the familiarity of the problem make it easy to ignore what a philosophical puzzle is involved in the simple 
phrase "ethical criticism." From one point of view, there is nothing extraordinary about it, for literary criticism has been seen, ever since Plato, as serving moral philosophy. To speak of ethical criticism, however, is to fall into either redundancy or oxymoron, and as such, literary criticism does enter crisis with Plato. Either literary criticism is seen as a branch of ethics, one of the many disciplines used by ethics to exert control over different areas of thought, or criticism exists at odds with ethical requirements in its quest to chart poetic form not within the ethical domain of truth but within the strange and elusive domain of fiction. In the first case, criticism obeys the imperatives of ethics to keep literature within the bounds of moral integrity. Ethics and criticism are synonymous, and to call criticism ethical is repetitious. In the second case, criticism strives to diverge from ethical requirements to establish its own identity and objectives and to invent a unique standard of literary content and form. Here, to call criticism ethical is to commit the most perverse of oxymorons, for criticism and ethics are antonymous. Ethics is supposed to be concerned with justice, and criticism is most banal and predictable when it makes judicial claims, even in the form of poetic justice. Indeed, the moral philosopher should be threatened, or at least deeply embarrassed, by the literary critic's allegiance to fiction.

Is there not a profound error in the idea that literary criticism discovers its own nature by adhering to ethical requirements? Literary theory has tended of late to answer this question in the affirmative. The view that literary criticism is subject to ethical demands has acted within recent critical history more and more as a challenge to literary theorists to put an end to the situation. In modern times, the history of literary study almost always represents this challenge in a particular way. Criticism and literature are to be liberated from morality to ensure the freedom of the literary imagination and to allow literature to pursue the path most suitable for its individual and special development. The attack on historical and biographical criticism by the American New Critics, for example, never failed to give as its rationalization the necessity of freeing literature from the demands of external forces. The familiar opposition between "extrinsic" and 
"intrinsic" criticism takes for granted that literary and nonliterary standards need to be divided. Indeed, the study of "literariness" has been identified as the true object of criticism by thinkers from the most opposing schools. René Wellek defines comparative literature as the discipline that pursues the problem of literariness across national boundaries, leaving behind the narrow view of comparative literature as a study of influences between two or more countries or national authors. Jonathan Culler similarly concludes in "American Critical Debate" that "criticism advances by becoming increasingly formalistic, as linguistics does" (5); and Paul de Man states with authority that criticism pursues the study of letters and not of mankind. ${ }^{2}$

No doubt criticism seeks the freedom to cut its unique path. But "freedom" is not a neutral term; it belongs to the ethical tradition. To understand the crisis of criticism, one must ask from what criticism seeks to be liberated. If it seeks freedom from ethics, what is it about ethics that is so disturbing? And if modern ethics exists to guarantee freedom, equality, and nonviolence, should not ethics pit itself against the very elements that literary criticism finds disturbing in ethics? It grows apparent that the critical act does not lead to an exit from ethics at all. ${ }^{3}$ Rather, the idea of criticism strikes to the heart of an ethical crisis concerning the nature of ethics. The rebellion of criticism against ethics belongs to the struggle of ethics with itself. The ethical substance of moral philosophy has come to be an element of scandal and a source of crisis, and critical theory today shares this element of scandal with ethics.

To chart the opposition of ethics to ethics would mean writing a history of moral philosophy. Here I can propose only a brief

2. Jonathan Culler, "Issues in Contemporary American Critical Debate," in American Criticism in the Poststructuralist Age, ed. Ira Konigsberg (Ann Arbor: University of Michigan Press, 1981), pp. 1-18. The paraphrase of de Man is from Stephen Greenblatt, ed., Allegory and Representation (Baltimore: Johns Hopkins University Press, 1981), p. viii.

3. See Murray Krieger's historical survey "In the Wake of Morality: The : Thematic Underside of Recent Theory," New Literary History 15.1 (1983): 119-36. Krieger argues that no one on the current scene escapes membership in the "moral gang." Note also that this issue of New Literary History is devoted to "Literature and/as Moral Philosophy." 
and necessarily incomplete overview that seeks to expose, from a literary point of view, how the critical enters the ethical, how the ethical enters the critical, and how each has tried through various means to rid itself of the other. Remarkably, each one tries to eliminate what it finds most disturbing in itself under the name of the other, and what distresses both about each other is a certain collusion with violence. In effect, ethics expels its ethical substance as the violence of critical judgment, and criticism struggles to free itself of its own violence by rejecting ethics.

Historical surveys tend to suggest exceptions more often than the rule, and I intend my remarks not as a survey of historical moments but as an overview of some case histories in which the interference between ethics and criticism is especially acute. Plato, of course, stands at the center of the debate concerning the validity of associating ethics and criticism; indeed, the history of his reception duplicates the history of the debate on ethical criticism. Those moral philosophers interested in literature as well as the great literary defenders of poetry have sought traditionally to reinterpret Plato or to use his arguments for their own purposes. This explains in part why Plato is often named as the origin of the crisis in criticism. Yet Plato did not believe that criticism was in crisis. He believed that literature and the arts were in crisis. Literature invites a pluralistic stance that threatens political regime, and consequently the moral philosopher takes a firm hold on critical tools for the purpose of making the adjustments necessary to enforce the civil requirements of justice and to bring poetry into agreement with the moral strictures of the city. Literary criticism is for Plato the unreluctant enforcer of ethical principles, and it ensures that literature provides only positive models of behavior. In fact, literary criticism remains so dependent on ethics in Plato that we speak only with difficulty of a Platonic literary theory. Historians of criticism generally agree that literary theory begins only with Aristotle.

Although Plato's argument is well known and often repeated, it apparently holds little persuasive power for the modern reader, who is inclined to see Plato's remarks on poetry and government as tyrannical. Part of the issue of ethical criticism will be to reflect on this peculiarly modern perception, and I will return to 
the problem. It is surprising to note, however, how little Plato's totalitarian leanings have been used against him within the tradition of poetic defense. Most of the great defenses of poetry struggle to redeem poetry within the rules set by Plato's argument. Few conceive of dismissing Plato's rejection of the poet purely on the ethical grounds that the gesture is violent and repressive. 4

Despite the modern perception of Plato, however, his argument has no equal in its ethical influence on critical method and poetic defense. The Republic best demonstrates the Platonic method of practical criticism. ${ }^{5}$ In Plato's eyes, poetry is savagely chaotic and a definite threat to the order of the republic. By encouraging acting, impersonation, and pretense to science, it imperils the Delphic wisdom of knowing oneself. Literature entices citizens to play more than one role, destroying the possibility of justice. For Plato's idea of justice depends on the neat prescription that one person have one responsibility: "justice is keeping what is properly one's own and doing one's own job. . . . Suppose a builder and a shoemaker tried to exchange jobs, or to take on the tools and the prestige of each other's trade, or suppose alternatively the same man tried to do both jobs, would this and other exchanges of the kind do great harm to the state? . . . I think you'll agree that this sort of mutual interchange and interference spells destruction to our state" (5.434).

Plato repeatedly described drama and poetry in terms of their ability to bring disorder into the order of the state. Acting especially has disastrous effects: "it is unsuitable for our state, because there one man does one job and does not play two or a multiplicity of roles" (3.397e). Plato genuinely feared artistic mimesis, as René Girard has argued, because he believed that it tempts people to appropriate each other's roles and invites com-

4. See Karl Popper, The Open Society and Its Enemies, 2 vols. (Princeton: At the University Press, 1966). To my knowledge, Popper is the first to remark the similarities between Plato's idea of the state and totalitarianism. His book, written in the shadow of World War II, is a remarkable example of how historical events influence different interpretations of philosophical and literary works, for Plato was usually associated, before Popper, with utopian views of government.

5. Plato, Republic, trans. Desmond Lee (New York: Penguin, 1974). 
petition and violence. ${ }^{6}$ Representation is, in fact, a mirror on the rampage, duplicating and reproducing its surroundings until nothing but chaos remains: "take a mirror and turn it round in all directions; before long you will create sun and stars and earth, yourself and all other animals and plants, and furniture and the other objects we mentioned just now" (10.596e).

When Plato expelled the poets from his republic, his intention was to eliminate social violence. This aspect of Plato's enterprise is rarely emphasized because it lies concealed beneath his allegories. The philosophical tradition interested in epistemology has ignored the ethical implications of Plato's expulsion of poetry and interpreted it in terms of the argument against inspiration and for true knowledge. Similarly, the Platonic equation between justice in the state and in the individual has encouraged moral philosophy to stress the idea of mental rather than social conflict, even though Plato described the antagonism between the three parts of the soul with the metaphor of "civil war." Each part of the soul, like each class in the republic, must adhere to its own role if order is to survive. No part of the soul may pretend to be another or challenge another's authority. In short, Plato's ethical and aesthetic philosophies are one. He reads Homer in the same manner that he reads society, and his final objectives, the good and the beautiful, reveal in their absolute natures to what degree Platonic philosophy serves an ethico-aesthetic ambition. What is ultimately most striking about Plato, however, is that he is more successful as a literary critic than as a social reformer. His most extended examples of what does not belong to proper conduct are based either on literary works or on analyses of political "characters."

The great question introduced by Plato is why does ethical theory continually represent social conflict in literary terms? How does literary criticism's view of literary form become an extended "allegory" for the ethical struggle with social violence and disorder? The great paradox of Plato, and it is the paradox with which both moral philosophy and literary criticism will

6. See Girard's reading of Plato in Des choses cachées depuis la fondation du monde (Paris: Grasset, 1978), pp. 15-18. 
never cease struggling, springs from the fact that ethics expresses its concern with the violence of society in literary forms, but then rejects literature as "violent." The opposition of ethics to literature becomes a bewildered attempt to reject its own efforts to formulate a coherent ethical theory. This is why the solution to Plato is not to strip away his poetic allegories to reveal political conflicts. To expel Plato's allegory for an ethical purpose is to repeat the Platonic gesture par excellence.

Although Aristotle did not argue for an unethical criticism, he was perhaps the first to lead literary theory away from the requirements of ethical form. I do not mean to give Aristotle Kantian motivations. Aristotle's separation of ethics and literary theory attempts to undo the paradox of ethical criticism: he divided ethics and criticism so that ethics might take advantage of its literary formulations without having to judge them at the same time. But Aristotle's gesture remains incomplete, and comparing the ethics of the Poetics to that of the Nicomachean Ethics, as has been the practice of classicists recently, suggests an unusual interplay. Whereas the Nicomachean Ethics stresses that moral agents must aim for a mean in their conduct, Aristotle argues in the Poetics that the best tragedies include characters who are unable to avoid committing a murder. Tragedy fails, in Aristotle's estimation, when characters intend to do evil and reverse themselves at the last minute. Aristotle, unlike Plato, was interested in literary characters who miss the mark (hamartia) in their pursuit of moral excellence, and this emphasis appears to keep poetry and ethics on separate ground. The obvious exception to the rule is Aristotle's praise for the ethical plot of the Iphigenia, in which a recognition prevents a human sacrifice, but Aristotle's esteem for the play is not matched by equal weight in his argument, and, in the final analysis, it is Oedipus the King, the drama of fateful violence, that serves to define tragedy. The tragic hero, it seems, is doomed to fall short of the standard of moderation required by the Nicomachean Ethics, and Aristotle, like Plato, ends by defining literature as ethically troublesome. The point is not, however, that ethics and criticism have nothing in common or that Aristotle considers tragedy an unethical form. The point remains that the complicated statements of literary forms do 
contribute to moral philosophy because they present it with an example with which to test its laws as well as an instance of practice and particularity to temper the generalities of ethical theory. ${ }^{7}$

Moral philosophy in Aristotle tries not to expel its own theories in the form of literary judgments, but to retain its literary formulations in their most antithetical and threatening forms within the scope of moral philosophy. Literature, for Aristotle, reveals the instability of human existence and the difficulty of living morally in such a world. Aristotle's approach was decidedly anti-Platonic, but his goals were not. Aristotle's purpose was to discover a series of limits in order to guarantee the integrity of the city and to protect citizens from both outside and inside violence. That he refused, however, to banish literature, despite its apparently conflictual character, that he established literature as an instrument for judicial contemplation, opened the humanistic age of ethics, in which ethics advances toward the possibility of a political rather than a transcendental formation. Literature exists as the other of ethics within the boundaries of the state, and it acts continually as a reminder to moral philosophy of the need to question itself.

The classicists, who stress this interplay, have been led to suggest another interpretation of Aristotle's theory of catharsis. ${ }^{8}$ Catharsis does not strive to purge those emotions that threaten the ethical stability of the city. Tragedy presents the city with its own political and ethical flaws in an act of clarification and selfdefinition, and it is this all-too-human nature that the population both fears and pities. Tragedy focuses on the political dimension of ethics. It reveals that standards of justice are the products of political decisions and not of ideal forms, thereby making it possible to debate those standards of justice.

7. Gerald Else, in Aristotle's Poetics: The Argument (Cambridge, Mass.: Harvard University Press, 1957), attempts to merge Aristotle's ethics and poetics, highlighting the Iphigenia in particular because it rewards good characters. More recently, Kathy Eden has proposed a reading of the Poetics that discloses Aristotle's judicial idea of tragedy. See Kathy Eden, Poetic and Legal Fiction in the Aristotelian Tradition (Princeton: At the University Press, 1986), pp. 25-61.

8. See the remarks on catharsis in Martha C. Nussbaum, The Fragility of Goodness (Cambridge: At the University Press, 1986), pp. 378-94. 
And yet for all of Aristotle's achievement, and his opposition to Plato, he ends by separating ethics and literary theory, if only for the purpose of holding them together. Modern scholars may struggle to merge his ethics and poetics, but we do not know that he undertook the task himself, and his separation of poetic making and moral practice ends by affirming within the history of literary criticism not an Aristotelian but a Platonic solution: ethics and criticism join only in the mutual effort to banish each other.

In summary, then, only a minor difference exists between the combination of ethics and literary criticism by Plato and Aristotle. For Plato, literature served to promote a positive view of ethical behavior. For Aristotle, it provides the "flaw," the negative example, upon which judgment and moderation are to be based. Classical literary theory is therefore defined as the discipline that systematically collects the guidelines by which literature either enforces or contradicts ethical laws with a view to strengthening moral philosophy's vision of itself. In either case, literary criticism is deprived of an ethical substance. It has little creative role in the founding of ethical principles. Rather, its ethical motivations are supplied and judged by philosophy.

With Kant, however, ethics enters the age of criticism. Kant's critical ethics brings together critical and moral philosophy in a single objective: the resolution of conflict. Kant's project takes three forms. First, criticism, as Kant defined it, intervenes within the philosophical tradition as a means of breaking the longstanding opposition between dogmatism and skepticism. It works to bring controversy to an end by detecting its sources and presuppositions. Second, the application of practical reason, or the ethical, is designed to resolve the conflicts implicit in ethical choice. Finally, Kant worked to resolve the conflict between ethics and aesthetics. In The Critique of Judgement, he departed from the classical tradition by giving aesthetics a creative role within the practice of ethics, for "Beauty is the symbol of morality" (\$59). 9 The accent must be placed on the word

9. Immanuel Kant, The Critique of Judgement, trans. James Creed Meredith (Oxford: At the University Press, 1957). My reading of Kant draws inspiration from Hannah Arendt, Lectures on Kant's Political Philosophy (Chicago: At the 
"symbol," as Ernst Cassirer understood, because art affects morality in purely representational terms.

If Plato and Aristotle described literature in its capacity to symbolize violence and competition, Kant broke with them by making literature the symbol of freedom. In Kantian philosophy, literature creates its own domain and elevates it above the clash of the world. The freer the work of art, the richer it is for taste. For "Taste is," Kant explained, "the faculty of estimating an object or a mode of representation by means of a delight or aversion apart from any interest" (\$5). Literature excites the idea of a world free of interest, competition, and violence, and as such, it provides the image of the goal toward which ethics should strive. Only literature captures the inscrutability of the idea of freedom upon which the entire program of Kant's moral philosophy rests.

Kant's aesthetics and ethics always return to the idea of freedom, for the paradoxical "duty" of art is to provide the ideal image of autonomy to the willing subject. Kant's emphasis on freedom demonstrates the degree to which he departed from Plato's vision of society, even though he stressed his debt to Platonic idealism. Kant differed from Plato in holding that the freedom of art no longer risks introducing chaos into the governing body, but instead designs the model for a world of free personalities, a republic of self-sufficient subjects purposively united. For Kant, art is the production of freedom by freedom, not the lie of inspired and insipid poets; it designs the ideal form of ethical practice. Most important, Kant's idea of beauty cannot exist, as Plato's and Aristotle's can, within the totalitarian state. In Plato especially, literature is denounced because it introduces a frightening plurality into his hierarchical regime. Contrarily, Kant required that "pluralism" be part of the state, but he defined it not in terms of a multiplicity of interpretations, as modern literary critics do, but in purely human terms. Pluralism, as

University Press, 1982), and Ernst Cassirer, Kant's Life and Thought, trans. James Haden (New Haven: Yale University Press, 1981). Also valuable are Paul Guyer, Kant and the Claims of Taste (Cambridge, Mass.: Harvard University Press, 1979), and Paul Guyer and Ted Cohen, eds., Essays in Kant's Aesthetics (Chicago: At the University Press, 1982). 
Kant explained in his Anthropology, represents the attitude of not being occupied with oneself as the whole world but regarding and conducting oneself as a citizen of the world.

Kant's idea of pluralism is inseparable from his anthropology. His moral philosophy demands a radical anthropology because he refused to conceive of freedom apart from human activity and willing. Freedom in Kant always refers to human liberty, not to a freedom of objects or interpretations. Kant proceeded from the nature of the human, and his critical philosophy assumes that nature provides the conditions of possibility for ethical freedom and action. Similarly, human nature guarantees aesthetic communication by ensuring that all people share an equal capacity for experience. Kant required that judgments of taste be valid not egotistically but pluralistically. Art cannot exist without morality, most significantly because beauty is communicable only provided that there is human equality or, as Kant expressed it, "the subjective conditions of this faculty of aesthetic judgement are identical with all men" (\$38). The universal communicability of taste requires the human context that Kant called "universal subjectivity," that is, the common ground of cognition and autonomy shared equally by all individuals.

Kant's idea of freedom, in both the ethical and the aesthetic senses, depends on the ability to make impartial judgments. The categorical imperative legislates that personal interest cannot become the rule for general ethical conduct. One may universalize one's desires only if they are in everyone's interest because truly selfish interests once universalized would destroy personal freedom once and for all. If thieves present their behavior as a universal code of conduct, for example, they guarantee that others will steal their goods, and private property will cease to exist. Similarly, aesthetic judgment requires complete impartiality of interest. "Every interest," Kant concluded, "vitiates the judgement of taste and robs it of its impartiality" (\$13). If an object of contemplation has a personal interest for the judge, it cannot be defined as beautiful. Both aesthetics and ethics require human beings to renounce purely individual interests in favor of universal principles.

What is at issue in Kant's description of aesthetic impartiality? 
It is again a matter of freedom from social violence, for Kant was interested in describing how freedom places constraints upon itself. At the most fundamental level, the renunciation of personal interest acts to defer conflict over objects. Here Kant returns to his classical origins. Plato expelled artistic representation because he associated it with an excessive freedom and disorder; he believed that art encourages citizens to compete over roles and responsibilities. The difference remains, however, that Plato laid the foundations of totalitarianism by assuming that some individuals have a superior knowledge of how a people's freedom must be limited in order to free them from personal interests. Kant held that the universal interest of free subjects dictates naturally which personal interests have to be sacrificed in the interest of freedom.

The problem of moral and aesthetic disinterest, however, does introduce a paradox into Kant's critical ethics. The categorical imperative demands that personal interest be renounced for the sake of ethical conduct; yet the realm of moral practice is ultimately one of interest, albeit common interest, because its objective is perpetual peace. A similar problem arises in matters of taste because aesthetic disinterest eventually implies the intervention of moral interest. At first glance, the satisfaction that determines taste seems devoid of interest, for Kant concluded that any judgment tinged by the slightest interest will be partial. Beauty possesses a purely symbolic purpose based on the "analogy" between ethical and aesthetic autonomy. It exists to give the pleasure of freedom that is universally communicable without being based in concepts, and literature must remain free of moral demands if it is to fulfill its promise. Nevertheless, aesthetic judgment cannot escape a certain interest because aesthetic disinterest symbolizes the moral freedom in which humanity places the greatest hope. The paradox can be summarized as follows. Literature represents the image and conditions of possibility for the ethical, but it must be isolated from morality in practice to remain the image of the ethical. Simply put, literary criticism must expel morality to guarantee the ethical purity of literature.

Ethics cannot be practical if it relies on the fact of freedom. To 
have any value, however, moral philosophy must be practical, and therefore its purest elements must be compromised to have any impact in the world of human action. Kant's solution to the paradox remained purely symbolic, and it has received varied acceptance by subsequent thinkers. Kant once more relied on the creative dimension of art to disclose a new path. He argued that the paradoxical designs of ethics are united in the feeling of art: in the free play of the powers of the mind, nature appears to the perceiver as if it were a work of freedom. The solution is only an image, an aesthetic judgment, but it allows individuals to pass into teleological judgment and a synthesis of ends. The end is the mental principle of union that judgment applies to the totality of experience. It manifests itself in the idea of a formal purposiveness in nature and in art. The concept of something that is its own end, however, belongs purely to the idea of freedom, not to the realm of nature. Only aesthetic judgment permits us to transform nature into the image of freedom, into the hypothesis of freedom's conditions of possibility. The "peculiar causality" of the end in itself designs the circle of the will's freedom, but Kant allowed art to share in that freedom; and in the fact that freedom belongs to willing and art uniquely lies the unity upon which Kant based his hopes for the emergence of his "culture of moral feeling."

Influenced strongly by Kant's claim for art, the Romantic generation gave literature an even more creative role in ethical understanding. Poetic language serves as the instrument through which the Romantic poet teaches others the essential moral nature of mankind. ${ }^{10}$ Two problems arise, however, with the Ro-

10. In A Defence of Poetry, Shelley insisted that "poetry acts to produce the moral improvement of man" (487). Although Shelley broke with Plato in his essential description of poetic inspiration as false, he realized the potential for moral education that Plato ascribed to literature. To reconcile his allegiance to Plato and to Rousseau's democratic ideals, he inverted Plato and gave literature the moral capacity to envision human equality and freedom. In this regard, the Romantic love of metaphor becomes a cipher for the democratic ideal of equality. In the Defence, Shelley claimed that early human language was vitally metaphorical, serving to mark the "before unapprehended relations of things" (482). Shelley's definition of "relations" is essentially democratic. "Relations" means "similitudes," what Bacon referred to as "the same footsteps of nature impressed upon the various subjects of the world" (482). And these "relations"-in the largest 
mantic project. As creators of poetic language, poets risk isolating themselves from their equals as either hierophants or martyrs to a holy cause. The uniqueness of genius, which Kant counterbalanced with the common sense of taste, proves an attractive temptation for the aspiring poet, and the majority of Romantic poets made a point of remarking that their special gifts set them apart from others. The cult of the artist undermines the principles of equality and freedom whose cause first stirred the poetic imagination of the nineteenth century. As Schiller expressed it in On the Aesthetic Education of Man, poets metamorphose through their craft and return to their own age as alien figures, not to gladden it, but to cleanse it. ${ }^{11}$

sense, human relations-afford the motives of equality, diversity, unity, contrast, and mutual dependence according to which human beings act and will within society. The great secret of morals and poetry is love, because Shelley's idea of love realizes the essence of relation: love is in his mind "a going out of our own nature, and an identification of ourselves with the beautiful which exists in thought, action, or person, not our own" (487). Wordsworth, in the Preface to the Lyrical Ballads (1800), similarly ascribes the pleasure received by the mind from metric language to the perception of "similitude in dissimilitude" and the reverse. This perception, Wordsworth believed, is the great spring of the human mind, enlivening sexual appetite, human conversation, and moral feelings. Love and metaphor in Romantic theory provide mankind with the moral sympathy necessary to find identity in difference and to stand in another's place. If poets are the unacknowledged legislators of the world, it is because they enact with their art and language the fundamental principles of a free social existence. It is only a matter, as Shelley said, of stripping away the "temporary dress" of the poet's creations to discover "the eternal proportions of their beauty" (487). See Percy Bysshe Shelley, "A Defence of Poetry," in Shelley's Poetry and Prose, ed. Donald H. Reiman and Sharon B. Powers (New York: Norton, 1977), pp. 478-510.

11. Schiller's On the Aesthetic Education of Man is often named as using Kant wrongly to enshrine art, but Schiller's inclinations were largely those of his contemporaries. Schiller gave aesthetics an even more active role in ethics than did Kant, arguing that mankind must pass through the aesthetic condition, from the sensual, to reach the ethical. Literature restores mankind to itself after the fall. It reintroduces human beings to freedom, for Schiller believed that "Art is a daughter of Freedom" (26). Most important, beauty is not merely a symbol of freedom, as Kant described it; "it is through Beauty," Schiller explained, "that we arrive at Freedom" (27). The risk in imposing any moral system remains that it may destroy the plurality of nature: the essential equality of people that the Romantics associated with emotional compatibility, human sympathy, and the nature of sensibility. Schiller's solution was to propose that literature has the ability to mediate between the two distinct realms of nature and culture by 
The second danger to the Romantic ethical project concerns poetic language itself. As language acquires greater power to embody the ethical, it also assumes greater responsibility for moral success and failure. If language partakes of the moral, it can be guilty of spreading immorality, and here the Platonic theory of poetry receives a renewed vigor. Wordsworth, for example, admitted with many others that the violence of his day revitalized poetic language, but he felt increasingly guilty that his poetry took substance and inspiration from the power of violence. In "Upon Epitaphs (3)," Wordsworth confessed that "words are too awful an instrument for good and evil, to be trifled with; they hold above all other external powers a dominion over thoughts. . . . Language, if it do not uphold, and feed, and leave in quiet, like the power of gravitation or the air we breathe, is a counter-spirit, unremittingly and noiselessly at work, to subvert, to lay waste, to vitiate, and to dissolve" (129-30).12 Just as the unique genius of poets (à la Plato) makes them responsible for the immorality of their work, the awful instrument of language exerts a special duty in ethical affairs. Language in Romantic theories possesses the capacity to vitiate and reorient thought, and it must be used responsibly if its potential for violence is not to be unleashed on human society.

The Romantic shift from moral action to language is admittedly subtle, but it has an enormous impact nevertheless. It prepares the way for the importance given by some modern philosophers and literary critics to language over human action. In twentieth-century Anglo-American philosophy-in the work of C. L. Stevenson, for instance-the idea of linguistic autonomy supports the belief that moral philosophers may discuss only the language of ethics, not conduct itself. Similarly, literary critics have tended to interpret the autonomy of literature not as a symbol of ethical freedom but as a property of literary repre-

lending to the unity of physical society the plurality of nature. See Friedrich Schiller, On the Aesthetic Education of Man, trans. Julius A. Elias (New York: Frederick Ungar, 1965).

12. William Wordsworth, "Upon Epitaphs (3)," in Wordsworth's Literary Criticism, ed. Nowell C. Smith (Oxford: At the University Press, 1925), pp. 123-43. 
sentation. The famous gap between the signifier and signified discovered by semiology ensures the belief that language is distinct from other phenomena. Among the New Critics and poststructuralists in particular, the principle of linguistic autonomy underlies the special status given to "poetry" and "textuality" and contributes to the idea that no form of language can be grounded in external phenomena.

The shift between human and literary autonomy is a peculiar feature of both modern ethics and literary criticism, and it derives its strength from the emerging importance of language as the interpretive category of modern thought. Most important, the shift ends by radically altering Kant's idea of pluralism, robbing it of its human context and transforming it into an issue of language. Indeed, the worse offense that one can commit today is to ground a literary interpretation in an anthropological bias. Nevertheless, the fact that linguistic autonomy and plurality in interpretation are defended with such moral enthusiasm suggests that they may yet carry the symbolism that Kant afforded them. Even among the most strident opponents of ethical criticism, the fight to preserve the autonomy of literature from morality can be justified only if it furthers the ends of ethics.

Before I turn to the current view of ethical criticism, however, it is necessary to consider Nietzsche's contribution to the notion of pluralism because it had a profound effect on ethics in general. Nietzsche transformed the notion of pluralism into precisely what Kant most abhorred: the idea of being preoccupied with oneself as the whole world. In Nietzsche's world, autonomy and ethics exclude each other, and the human race is composed of a plurality of radical individuals in which each person struggles with every other in a contest of wills. Moral language obeys the will to power; it is nothing but a system of representations intended to conceal emotions and to manipulate other people. Similarly, literature exists to express power and hardly differs from morality.

Since everything, in Nietzsche's view, has a common source in the will to power, he had no reason to oppose criticism and ethics. Nietzsche's singular view of metaphysics has been called an inverted Platonism, and he certainly seems to have applied 
Plato's view of literature to ethics. Now ethical theory, not poetry, represents the lie of those drunk with the desire for power. Ethics is a system of inspired falsehoods designed to reverse the natural order of human might and to give power to those who possess neither real knowledge nor merit. Nietzsche may have inverted Plato, but he did not dispute that literature is largely immoral. The surprise is that Nietzsche believed that literature expresses, by virtue of its immorality, the only truth possible, that is, the untruth of ethical language. Thus literature frees itself from ethics at last by discounting ethics as mere literature.

It is currently fashionable to credit Nietzsche as the philosopher who exposed the metaphorical nature of ethical truths. Poststructuralist theorists return habitually to his essay "On Truth and Lie in the Extra-Moral Sense" to debunk the will to truth as mere anthropomorphism. Apparently, for them, Nietzsche makes it possible to pass beyond Kant's anthropological emphasis by discovering the primacy of language in human history. But Nietzsche's preoccupation with language was limited; he had literary pretensions to be sure, especially for his style, but his principal interest was ethics and not literature. Nor did Nietzsche dismiss the anthropological context, as many wish to claim. His philosophy is notorious precisely because he refused to abandon the anthropological definition of pluralism. Pluralism, for Nietzsche, refers to the inescapable isolation of every person from every other and to the inexorable need of all persons to transform themselves into gods. Nietzsche's description of the will to power derives both its great originality and its horror from the fact that he pushes human selfishness to its limit. His vision of human society is pessimistic because he cannot conceive of any form of social agreement that would not serve violence and repression. The natural result is Nietzsche's theory of the overman, a superhuman individual who regulates his desires and behavior not for the sake of others or under the compulsion of social contract but for his own satisfaction.

Modern ethics and literary criticism both preserve Nietzsche's view of pluralism, but they blind themselves to its most dreadful aspects. They accomplish the task, as I noted, largely by interpreting pluralism as a linguistic rather than human category. 
The emotivists, for example, agree with Nietzsche that moral language exists only to vent emotions and to manipulate other people. Not being sufficiently Nietzschean, however, they conclude that moral language is too irrational to merit analysis. Modern critical theorists define pluralism as a literary or linguistic property, and, like Nietzsche, they view it as an expression of autonomy. Since they isolate language from its social context, however, they fail to see the inadequacy of their linguistic view of pluralism.

What lies behind the modern tendency to equate ethical behavior and linguistic pluralism? It relates in its most profound aspects to the struggle of ethics with itself over the issue of social violence. In "The Ethics of Linguistics," Julia Kristeva, although a believer in linguistic pluralism, gives a remarkably clear description of the view of ethics current in literary criticism. ${ }^{13}$ Ethics today must take as its primary aim the dissolution of the form of ethics associated with repression and violence:

Ethics used to be a coercive, customary manner of ensuring the cohesiveness of a particular group though the repetition of a code-a more or less accepted apologue. Now, however, the issue of ethics crops up wherever a code (mores, social contract) must be shattered in order to give way to the free play of negativity, need, desire, pleasure, and jouissance, before being put together again, although temporarily and with full knowledge of what is involved. Fascism and Stalinism stand for the barriers that the new adjustment between a law and its transgression comes against. (23)

Kristeva's political motives are stronger than those of the other pluralists present on the current scene. Nevertheless, she still

13. Julia Kristeva, "The Ethics of Linguistics," Desire in Language, trans. Thomas Gora, Alice Jardine, and Leon S. Roudiez (New York: Columbia University Press, 1980), pp. 23-35. This essay is not, however, a definitive statement of Kristeva's position. Elsewhere, for example, Kristeva departs slightly from her dependence on marginal ethics, expressing concern that marginality, especially that of women, is easily exploited by totalitarianism. But she still concludes that only a knowledge of the relativity of symbolic and biological existence poses an alternative to an ethics whose essence is largely sacrificial. See "Women's Time," trans. Alice Jardine and Harry Blake, in Feminist Theory: A Critique of Ideology, ed. Nannerl O. Keohane, Michelle Z. Rosaldo, and Barbara C. Gelpi (Chicago: At the University Press, 1981, 1982), pp. 31-54. 
defines ethics linguistically, making language the source of pluralism as such. To arrive at a "linguistic ethics," literary criticism must be deflected "toward a consideration of language as articulation of a heterogeneous process" (24). For Kristeva, heterogeneity, another term for pluralism, resides primarily in poetic language, a language that frees marginal, negative, and destructive causalities. The silent causalities of poetic language subvert repressive social regimes, exploding totalitarian structures and rigid models for daily existence. Traditionally, "coercive ethics" struggles to kill poetic language to achieve its stability. "Consequently," writes Kristeva, "we have this Platonistic acknowledgment on the eve of Stalinism and fascism: a (any) society may be stabilized only if it excludes poetic language" (31).

Kristeva's description of the struggle of ethics with itself differs from current opinion only to the extent that she states openly the political dimension of her choices. Her moral and political choice is to take the side of poetic language against society as such, and her apology for poetry consists of dismissing Plato's expulsion of the poet as a fascist gesture. For Kristeva opposes poetic language explicitly to murder, death, and unchanging society. Nevertheless, she remains within the Platonic tradition insofar as she accepts its description of poetry as marginal to social and moral behavior. Her choice is Romantic because she defines ethics simply as taking the side of whatever has been excluded by society. ${ }^{14}$ For Kristeva, ultimately, there

14. The same theoretical problems exist in the work of Michel Foucault. Foucault's allegiance to Romantic marginals, those expelled from history, reveals his history to be more anthropological than archaeological. His early ethics are explicitly transgressive, as Kristeva's are, and they focus on the freeing of desire from the forces of repression. Transgressive discourse captures the discourse of the subject, such as the discourse of madness explored in Madness and Civilization, and refuses to create a norm or to expel. Indeed, Foucault usually finds distasteful anything that recalls order, norm, or law, judging that any discourse on a subject in fact weighs upon and crushes it beneath a desire for discipline and order. Morality belongs for Foucault to the type of discourse that operates on subjects; it is essentially normative and regulated, and comprises finally a language useful only to order desire.

In The Use of Pleasure, however, Foucault seems at first glance to have abandoned this view. There he conceives of a subject of ethics who engages in an exercise of selfhood that is autonomous and free from the constraints of law. Nevertheless, upon closer inspection, Foucault's older views remain. He defines 
can be no society that is not repressively Platonic because every society has its victims: "The question is unavoidable: if we are not on the side of those whom society wastes in order to reproduce itself, where are we?" (31).

I treat Kristeva at such length because she exemplifies a certain Romanticism pervasive in modern critical theory. This Romanticism admits that Plato's description of poetry as antisocial is correct, but it embraces rather than banishes poetic language as the only hope for an ethical existence. Literature and society oppose each other, and the literary critic decides to stand with the marginal forces of literature. Literature comes to represent the last avatar of freedom within a vision that imagines human society as gruesomely totalitarian. Linguistic pluralism is Romantic because it bases its hopes on the inability of society to absorb the heterogeneity and irrationality of language. In this view, poetic language may sometimes be allied with cultural violence because its codings influence human behavior, but its properly contradictory nature also means that literature may take itself as its own object, turning upon itself to explode its repressive potential and to quench its own violence.

Linguistic pluralism assumes the fundamentally polysemic and ambiguous nature of language. With the New Criticism, poetry was understood as a symbol of freedom because its ironic and paradoxical nature could not be paraphrased by ordinary (social) language. W. K. Wimsatt's "Poetry and Morals," for example, concludes that one cannot really refute Plato because "a moral code must be by its nature too rigid to accommodate, or at least too rigid to account for or specifically sanction, the widely heterogeneous concreteness of the world's recognized poetry" (89)..$^{15}$ The New Critical defense of poetry explicitly inverts Plato's values by embracing literature's chaotic nature as repre-

"morality" as the laws of conduct and "ethics" as the practices of the self. His preference for the latter over the former preserves the taste for transgression and Romantic individuality so fervent in his earliest writings. For an extended discussion of Foucault and Romantic marginality, see my The Romantic Fantastic (Ithaca: Cornell University Press, 1984).

15. W. K. Wimsatt, "Poetry and Morals," The Verbal Icon (Lexington: University of Kentucky Press, 1954), pp. 85-102. 
sentative of its autonomy. "What Plato saw as the evil of poetry," Wimsatt explains, "the mixture of its emotions and the confusion of its advice, has become now, under such names as ironic 'tension' and 'synaesthesis,' the richness of aesthetic value" (91). Poststructuralism similarly asserts that the self-reflexive quality of language maximizes free play, describing linguistic structure in terms of its differential nature or its capacity to give insight into blindness. The popular deconstructive term "differance" allows no exclusive form of judgment because it both negates itself and permits an expansive and uncontainable dissemination of meaning. Whereas Plato associated poetry with the discovery of inconsistency and strife, modern criticism appraises poetry as good only if it presents the reader with paradoxes, negativities, and ironies.

If ethical theory has traditionally struggled to pass judgments and make decisions, the new ethical criticism differs by suspending judgment and embracing all interpretations, however contradictory. Thus Northrop Frye, in "Ethical Criticism," the second essay of Anatomy of Criticism, defines ethical criticism as the commitment to plurality in interpretation:

The principle of manifold or "polysemous" meaning, as Dante calls it, is not a theory any more, still less an exploded superstition, but an established fact. The thing that has established it is the simultaneous development of several different schools of modern criticism, each making a distinctive choice of symbols in its analysis. The modern student of critical theory is faced with a body of rhetoricians who speak of texture and frontal assaults, with students of history who deal with traditions and sources, with critics using material from psychology and anthropology, with Aristotelians, Coleridgians, Thomists, Freudians, Jungians, Marxists, with students of myth, rituals, archetypes, metaphors, ambiguities, and significant forms. The student must either admit the principle of polysemous meaning, or choose one of these groups and then try to prove that all the others are less legitimate. The former is the way of scholarship, and leads to the advancement of learning; the latter is the way of pedantry, and gives us a wide choice of goals, the most conspicuous today being fantastical learning, or myth criticism, contentious learning, or historical criticism and delicate learning, or "new" criticism. $(72)^{16}$

16. Northrop Frye, Anatomy of Criticism (Princeton: At the University Press, 1957). 
Frye's political and ethical motives are oblique, to say the least. He castigates the opponents of his "ethical criticism" not as enemies of the open society, as Kristeva does, but as academic pedants. Nevertheless, Frye's commitment to interpretive pluralism and poetic autonomy has its roots in a social context. Equating ethics with judgment rather than with pluralism risks Plato's cultural repression and violence. "As soon as we make culture a definite image of a future and perhaps attainable society," Frye writes, "we start selecting and purging a tradition, and all the artists who don't fit (an increasing number as the process goes on) have to be thrown out. So, just as historical criticism uncorrected relates culture only to the past, ethical criticism uncorrected relates culture only to the future, to the ideal society which may eventually come if we take sufficient pains to guard the educating of our youth" (346). Literature fights repressive regimes by freeing the imagination and making a liberal education possible. This is in itself ethical, according to Frye: "The ethical purpose of a liberal education is to liberate, which can only mean to make one capable of conceiving society as free, classless, and urbane. No such society exists, which is one reason why a liberal education must be deeply concerned with works of the imagination. The imaginative element in works of art, again, lifts them clear of the bondage of history" (347).

I do not want to dispute Frye's contention that the purpose of a liberal education is to liberate. What is disturbing about Frye's embrace of linguistic pluralism is the implication that judgment by definition cannot be ethical. The modern view of ethics tends to translate freedom of choice into freedom from choice, as if suspending judgment places one on the side of a higher morality and liberates one from the chains of social existence. If literature exists solely above the clash of the world, it has no value for the human race. A freedom defined apart from social reality, as purely literary, cannot be the model for freedom within society. One might even venture to suggest that it cannot be understood.

Not surprisingly, the problem of incomprehensibility has become part of the ethics of criticism. That language and literature are baffling is now commonly assumed by critical theory. Their 
incomprehensibility is necessary to the desire to separate art from the everyday world, to promulgate, apparently against Platonism, the Platonic gesture itself. No single theorist can be singled out as the unique proponent of this view. In this sense, none of the poststructuralists is original. The major figures rarely use the word "ethical," no doubt for fear of being unethical, and they usually do not make the association between the undecidable nature of language and ethical motivations. When critics do refer to ethics, it is almost a foregone conclusion that they mean some form of linguistic pluralism.

J. Hillis Miller's "The Ethics of Reading" is a good case in point. ${ }^{17}$ Miller represents the mainstream view of deconstruction in America, and he is not embarrassed to make its ethical assumptions clear. As Kristeva does, he opposes his ethics to the one that values truth. To dream of unification in matters of truth is hopeless, and neither humanism nor the nihilistic challenge to the value of humanity proceeds ethically when one insists on its own truth to the exclusion of the other's. Rather,

17. J. Hillis Miller, "The Ethics of Reading," in American Criticism, ed. Konigsberg, pp. 19-41. In this context, I also recommend the "Limits of Pluralism Debate" among Wayne C. Booth, M. H. Abrams, and Miller in the pages of Critical Inquiry 3.3 (1977), even though none of the participants really venture beyond the linguistic definition of pluralism. Miller's position remains similar to that in "The Ethics of Reading." Abrams's essay is essentially an attack on deconstruction and its claims to infallibility. Booth argues that the limits of pluralism are plural and focuses on the core of agreement shared in textual interpretation. More recently, however, Booth has turned explicitly to the study of ethical criticism. He stresses in particular the ethical motivations hidden in the "professedly anti-ethical and apolitical stances of modern aesthetic movements" and criticizes their attempts to forego judgment (49). See "Freedom of Interpretation: Bakhtin and the Challenge of Feminist Criticism," Critical Inquiry 9 (1982): 45-76.

For a special contribution to the debate over linguistic pluralism, see René Girard's "Violence and Representation in the Mythical Text," To Double Business Bound (Baltimore: Johns Hopkins University Press, 1978), pp. 178-98. Girard argues that not all texts can be interpreted pluralistically and proposes as an example what he calls the "texts of persecution," or documents of scapegoating, such as texts of medieval anti-Semitism, written from the perspective of the persecutors. According to Girard, linguistic pluralism and autonomy here succumb to morality, for "even the most rabid exponents of a textuality detached from any referent and entirely closed upon itself will relent when confronted with the texts of persecution. They will not only confess that a referent is in order, but they will identify that referent if asked to do so" (193). 
Miller argues that ethics must be modeled after epistemology and the fact that meaning is pluralistic and self-contradictory. Following Paul de Man, Miller insists that the most distinctive property of language is its tendency to unravel itself. The ethical stand par excellence, therefore, is to subject oneself to the words on the page and follow their example. The ethics of reading requires that readers make no decision to support any specific interpretation but that they allow the paradoxical and undecidable character of textuality to shape and coerce them. The necessity of this coercion obeys what Miller calls, after de Man, the linguistic imperative: "Es ereignet sich aber das Wahre," or "What is true is what is bound to take place" (41). If the linguistic imperative permits any truth, it consists in the requirement that reading "go against the grain of what one would want to happen in the name of what has to happen" (41). "The ethics of reading," Miller concludes, "is the moral necessity to submit in one way or another, whatever one says, to the truth of this linguistic imperative" (41j.

Miller's belief that the ethics of reading consists in the necessity of submitting to linguistic structure does not permit a great deal of freedom for literary critics. Indeed, it places them in what he calls the "cage of language." The formulation calls to mind a series of equally troublesome ideas. One thinks of Hegel's reproach against Kant that he subjected the "is" to the "ought," revealing to what degree the aesthetics of the third Critique relies on morality. Hegel's preference for the "is" or "what is bound to take place" made it easy for him to become the philosopher of Frederick William's Prussian absolutism. Miller's devotion to necessity also summons Aristotle's view of the teleology of character-that one can become only what one isan idea that meant in terms of Greek society that slaves must remain slaves, and aristocrats, aristocrats. Finally, does not Miller's idea of necessity invoke what Freud also called "Necessity," that is, Ananke, the inescapable imperative of human violence and death?

I do not want to suggest that Miller supports totalitarianism. I have already stressed, perhaps excessively, that linguistic pluralism evolves as an ethical response to the perception that so- 
cial language is repressive and violent. My point remains, however, that the creation of an isolated linguistic morality robs ethical theory of its social context and renders ethics ineffectual. Linguistic undecidability really amounts to a Romantic strategy designed to confront what is perceived to be the differentiating capacity of literature and language. It tries to turn a dangerous element into one that is self-reflexive and self-destructive in the hope that what is violent and threatening in language will defuse itself without any effort on our part. That language is necessarily ethical merely because it does not permit judgments (that it defers differences) is an idea whose absurdity will become increasingly apparent as time goes by. What the proponents of this view really desire is to return to primal chaos, to some pure state of nature, where men and women are mutes, and language does not exist to impose order or to corrupt. But the theorists of linguistic pluralism will never be free. Language has become their ruler, and they enslave themselves to it, making it their prison keeper and giving it powers in theory that mean their destruction in practice. They resemble the community of frogs in the fairy tale who regret having made the stork their master, after it becomes apparent that the bird is interested in dining on them rather than with them.

Pluralism may be applied through language, but it cannot have value solely as a linguistic category. If pluralism were defined in society the way literary critics define it, society as we know it would die. The judicial system would simply collapse in indecision, and every element abhorred by society would rise to power. As Kant understood, pluralism can have no value outside of an anthropological context.

Society can be a dangerous domain, as Romanticism has never tired of repeating, but man is and will no doubt remain a social animal. Moral philosophy as a result has been concerned throughout its history with purging from the borders of the city the disorder and violence that the city was born to contain. The process has not been necessarily just or simple. The philosophical tradition in particular has tended to occult how unsteady the progress of ethical ideas has been from their earliest concerns to the latest. In the earliest times, cultural forms were not rigidly 
associated with violence, as they were by Romanticism, but were described as a response to violence. The first meaning of "virtue" in Homer, for example, refers to performance in battle to preserve one's society. This is why Achilles' refusal to enter the Trojan War is such a radical act; and the Iliad traces as its plot the efforts of the Greeks to restore peace to their ranks so that they may defeat their enemies. In the end, Greek victory is assured only by redirecting Achilles' wrath against Agamemnon toward Hector, thereby restoring the difference between the inside and the outside and permitting the Greeks to have an enemy once more.

Ethics in modern culture is more political, however, in the sense that it is concerned more with the justice of its own civility than with the morality of its enemies. Romantic ethics created this focus. The Romantics formulated the problems of social existence in terms of civilization and its discontents, and they belong to the modern phase of ethics insofar as only modern culture has the time to examine its own inadequacies and injustices. That modern culture remains discontent with itself is, ethically speaking, its most redeeming feature.

The modern emphasis on undecidability could no doubt be traced to such impulses, and liberal education has implicitly accepted the task. Because liberal education, as Frye remarks, is concerned with liberation, it chooses to look at the crisis of ethics from an inside view. It enters into crisis as a means of understanding it. Yet the project casts aspersions on the humanities. That the liberal arts are in crisis represents a serious threat to the humanists' claim that they make a contribution to modern life and education. The inability to make decisions, for example, marks literary studies as a soft discipline in an age that demands hard facts, and opinion increasingly gathers that the liberal arts have fallen behind the times. But the human sciences are not obsolete. That criticism is in crisis signals not that it is behind the times but that it has entered an advanced stage in the ethical concern with social violence. The present crisis in literary criticism reflects the tendency of modern ethics to turn its focus inward to the interpretation of its own laws and the nature of interpretation as such. In fact, it represents a characteristically 
modern impulse, for modern culture may be defined as a period of anxious concern over its own arbitrariness, that is, over its tendency to control violence arbitrarily in the manner of violence itself. It follows, incidentally, that the modern theory of the arbitrariness of the sign is not generally responsible for placing critical language in doubt. The theory became possible only because modern thought is preoccupied with arbitrariness as the method of violence. ${ }^{18}$

Modern literary critics are almost unanimous in the belief that the act of decision is violent. They understand that decision, like criticism, requires that a cut be made. But decision is not immoral by definition, and ethical theory is hardly served by rejecting the responsibility for making judgments. Indeed, the essential principles of ethics cannot be preserved without the capacity to make decisions. Totalitarianism abolishes as its first step toward power the right to judge for oneself. The totalitarian state understands only too well that freedom and decision are inextricably bound to each other.

Similarly, literary criticism cannot endure without the freedom to make judgments, and modern theory urgently needs to regain the capacity to decide. Criticism requires the right to judge in favor of a single interpretation in order that many interpretations may exist. Begin by rejecting all interpretation, and one ends by accepting any interpretation. As it stands, modern criticism has lost its sense of purpose. Perhaps its greatest failing has been its refusal to judge the difference between literature and life, for this activity is the definitive characteristic of crit-

18. By "arbitrariness of the sign," I refer to the modern idea that the correspondence between sign and object is wholly arbitrary and motivated only by convention. That language is arbitrary is certainly an ancient idea: it may be found at least as early as Plato's Cratylus. Nevertheless, in every case, the doctrine of arbitrariness is compromised by some transcendental guarantee that language will refer despite its arbitrariness. Michel Foucault follows this tendency historically in The Order of Things (New York: Vintage, 1973), demonstrating to what extent most theories of the sign depend on metaphysical assumptions. The modern discourse of arbitrariness, however, is much more radical in its views. Only use establishes guarantees against arbitrariness, and when human use becomes subordinated to linguistic laws, as it is in modern criticism, use is not a strong guarantee. The gap between sign and object yawns, as language becomes more autonomous. 
icism. Entering into the conflict between life and literature does not necessarily mean dividing them. Literary criticism best evolves by installing itself in the space between literature and life not to hold them apart, but to bridge the gap. The conflicts that arise between life and literature, and between rival interpretations, comprise the dialogue in which it is the business of criticism to engage. Criticism properly understood means an end to the Platonic and Romantic belief in the marginality of literature, for it accepts the task of examining to what extent literature and life contribute to the nature and knowledge of each other.

Criticism cannot endure by keeping one eye nervously on society while continuing to focus on the autonomy of its pursuits and language. The critical desire to free literature from ethics is an ethical gesture that must fail if it is to succeed. Criticism needs rather to admit its role as a mediator between life and literature and to accept the ethical responsibilities of its judgments in both domains. Once the task has been accepted, ethics and criticism can no longer be divided. Literature cannot be free in an immoral climate, for ethical principles guarantee the freedom of literary expression. Nor can ethics develop or maintain itself without the creative spirit of literature. Ethics and criticism are inseparable. At its best, literary criticism is always ethical, and the best form of ethics is relentlessly critical.

For the critics who fear that all criticism is violent, the attempt to restore decision to literary theory will be seen as a restrictive and aggressive project. Those who decide to defer judgment, however, can escape neither the hypocritical pretense of indecision nor the ethical injustices of their choices. Nor can criticism be stripped of its teeth by proclaiming that theory is really literature, for literature is hardly free of violence and ethical decisions. Literature merely sublimates its judgments and aggression in plot and characterization. Kierkegaard said that the instant of decision is madness. He was referring to the choice between ethics and aesthetics, and no doubt he understood that the decision itself is ethical as only decision can be. The crisis of criticism belongs to the nature of this decision, and criticism 
cannot exist without it. The inescapable fact remains that criticism always makes decisions, if it is criticism, and therein lies its monstrous character for an age that views the instant of decision as madness. 